INDONESIAN HEALTH ISSUE

\title{
Hubungan Pengetahuan, Pendapatan Dan Makanan Pantangan Dengan Pola Makan Pada Ibu Nifas
}

\author{
Lasria Simamora ${ }^{1}$, Riska Susanti P. ${ }^{2}$, Deby Cintia Yun ${ }^{3}$ \\ 1,2,3 STIKes Mitra Husada Medan \\ Email korespondensi: lasriasimamora@gmail.com \\ No HP: 081370896872
}

\begin{tabular}{l}
\hline ARTICLE INFO \\
Received \\
01 Januari 2022 \\
Accepted \\
14 Februari 2022 \\
Published \\
19 Februari 2022 \\
\hline
\end{tabular}

Kata Kunci:

Pengetahuan;

Pendapatan;

Pantangan;

lbu Nifas

Keywords:

Knowledge;

Income;

Food Abstinence;

Post Partum Latar Belakang:Secara umum terjadi penurunan kematian ibu selama
periode $1991-2015$ dari 390 menjadi 305 per 100.000 kelahiran hidup.
Walaupun terjadi kecenderungan penurunan angka kematian ibu, namun
tidak berhasil mencapai target MDGs yang harus dicapai yaitu sebesar
102 per 100.000 kelahiran hidup pada tahun 2015 . Hasil supas tahun
2015 memperlihatkan angka kematian ibu tiga kali lipat dibandingkan
target MDGs. Kekurangan gizi pada ibu nifas atau ibu menyusui
menimbulkan gangguan kesehatan pada ibu dan bayinya.Gangguan
pada bayi mudah sakit, mudah terkena infeksi, kekurangan zat-zat
esensial menimbulkan gangguan mata, tulang dan pertumbuhan dan
pada ibu nifas akan memperlambat proses penyembuhan luka perineum.
Bila ibu tidak memperoleh makanan dengan gizi yang seimbang dapat
mengakibatkan ibu kekurangan gizi dan kekurangan darah dan ibu akan
memberikan ASI dengan jumlah yang sedikit kurangnya pemenuhan gizi
ibu nifas atau menyusui di sebabkan banyak faktor diantaranya adanya
pantangan makan pada ibu nifas. Tujuan: Menganalisis hubungan
Pengetahuan, Pendapatan dan Makanan Pantangan ibu dengan Pola
makan pada lbu Nifas. Metode: observasional kuantitatif kepada seluruh
ibu nifas yang berkunjung di klinik bersalin Citra sebanyak 32 orang,
Tekhnik sampel yang digunakan adalah total sampling. Hasil:ada
hubungan pengetahuan dengan pola makan ( $p=0,019$ ), ada hubungan
pendapatan dengan pola makan ibu nifas ( $p=0,017)$, tidak terdapat
hubungan yang signifikan antara dukungan keluarga dengan pola makan
( $p$ = 0,3811). Kesimpulan: Terdapat hubungan pengetahuan dan
pendapatan dengan pola makan ibu nifas, sementara dukungan
keluarga tidak berhubungan dengan pola makan ibu nifas.

\section{ABSTRACT}

Background: In general, there was a decrease in maternal mortality during the period 1991-2015 from 390 to 305 per 100,000 live births. Although there is a tendency to decrease maternal mortality, the MDGs target that must be achieved is 102 per 100,000 live births in 2015. The results of the 2015 SUPAS show that the maternal mortality rate is three times higher than the MDGs target. Malnutrition in postpartum mothers or breastfeeding mothers causes health problems for mothers and their babies. Disturbances in babies are easy to get sick, susceptible to infection, lack of essential substances causes eye, bone and growth disorders and in postpartum mothers it will slow down the healing process of perineal wounds. If the mother does not get food with balanced nutrition, it can result in the mother being malnourished and lacking in blood and the mother will give breast milk in a small amount, the lack of fulfillment of nutrition for postpartum or breastfeeding mothers is caused 
by many factors, including dietary restrictions in postpartum mothers. Purpose: Analyzing the relationship between Knowledge, Income and Food Abstinence of Mothers with Diet in Postpartum Mothers. Methods: there is a relationship between knowledge and diet $(p=0.019)$, there is a relationship between income and postpartum mother's diet $(p=0.017)$, there is no significant relationship between family support and diet $(p=$ 0.3811). Conclusion: There is a relationship between knowledge and income with the postpartum mother's diet, while family support is not related to the postpartum mother's diet. 


\section{PENDAHULUAN}

Pembangunan Nasional yang diselenggarakan oleh bangsa Indonesia pada hakekatnya merupakan pembangunan Indonesia yang seutuhnya dan pembangunan seluruh masyarakat Indonesia, yang meliputi lahiriah dan batiniah serta menjadi tanggung jawab pemerintah dan juga masyarakat sebagaimana yang diamanatkan dalam GBHN.

Masalah kesehatan ibu dan anak merupakan salah satu masalah utama dalam bidang kesehatan yang saat ini terjadi di negara Indonesia. Setiap tiga menit, disuatu tempat dilndonesia anak dibawah umur meninggal karena melahirkan atau sebab-sebab berkaitan dengan kehamilan. Sampai pada saat ini telah banyak program-program pembangunan kesehatan di Indonesia yang ditujukan guna menanggulangi masalah-masalah kesehatan ibu dan anak. Pada dasarnya programprogram tersebut lebih menitik beratkan pada upaya-upaya penurunan angka kematian bayi dan anak, angka kelahiran kasar dan angka kematian ibu (Unicef, 2014).

Upaya kesehatan ibu dan anak menjadi salah satu prioritas pembangunan kesehatan di Indonesia. Angka Kematian Ibu (AKI) merupakan salah satu indikator untuk melihat keberhasilan upaya kesehatan ibu. Oleh sebab itu lbu dan anak merupakan anggota keluarga yang perlu mendapatkan prioritas dalam penyelenggaraan upaya kesehatan, karena ibu dan anak merupakan kelompok yang rentan. Hal ini terkait dengan fase kehamilan, persalinan dan nifas pada ibu dan fase tumbuh kembang pada anak (Kemenkes, 2019).

Secara umum terjadi penurunan kematian ibu selama periode 1991-2015 dari 390 menjadi 305 per 100.000 kelahiran hidup. Walaupun terjadi kecenderungan penurunan angka kematian ibu, namun tidak berhasil mencapai target MDGs yang harus dicapai yaitu sebesar 102 per 100.000 kelahiran hidup pada tahun 2015. Hasil supas tahun 2015 memperlihatkan angka kematian ibu tiga kali lipat dibandingkan target MDGs (Kemenkes, 2019).

Upaya percepatan penurunan AKI dapat dilakukan dengan menjamin agar setiap ibu mampu mengakses pelayanan kesehatan ibu yang berkualitas, seperti pelayanan kesehatan ibu hamil, pertolongan persalinan oleh tenaga kesehatan terlatih di fasilitas pelayanan kesehatan, perawatan pasca persalinan bagi ibu dan bayi, perawatan khusus dan rujukan jika terjadi komplikasi, dan pelayanan keluarga berencana termasuk KB pasca persalinan.

Pelayanan kesehatan ibu nifas harus sesuai standar, yang dilakukan sekurang-kurangnya empat kali sesuai jadwal yang dianjurkan, yaitu pada periode 6 (enam) jam sampai dengan 2 (dua) hari pasca persalinan; pada periode 3 (tiga) hari sampai dengan 7 (tujuh) hari pasca persalinan; pada periode 8 (delapan) hari sampai dengan 28 (dua puluh delapan) hari pasca persalinan; pada periode 29 (dua puluh sembilan) sampai dengan 42 (empat puluh dua) hari pasca persalinan (Kemenkes, 2020).

Masa nifas adalah masa pemulihan paska persalinan hingga seluruh organ reproduksi wanita pulih kembali sebelum kehamilan berikutnya. Masa nifas ini berlangsung sekitar 6-8 minggu paska persalinan. Masa nifas ibu memerlukan zat gizi yang seimbang untuk kebutuhan tubuhnya, dimana nutrisi pada masa postpartum dan menyusui meningkat 25 persen berguna untuk proses penyembuhan setelah melahirkan serta produksi ASI untuk pemenuhan kebutuhan bayinya. Selain itu, nutrisi yang dikonsumsi berguna untuk melakukan aktifitas, metabolisme, 
cadangan dalam tubuh. Jika ibu nifas kurang dalam memenuhi gizi akan mengakibatkangangguan pertumbuhan bayi dan ketidak stabilan kesehatan ibu menyusui (Sukma Febi dkk, 2017).

Pemenuhan nutrisi maupun pola makan dapat dipengaruhi oleh berbagai faktor, diantaranya adalah umur, pendidikan, pendapatan, pekerjaan, pengetahuan, sosial budaya dan ekonomi (Mahayati, 2015). Penelitian yang dilakukan oleh Ramadhani et al., (2015) menyatakan bahwa pola konsumsi pangan ibu nifas pasca melahirkan dipengaruhi oleh faktor kepercayaan tentang pantangan makanan yang berasal dari lingkungan dan jenjang pendidikan.

Berdasarkan pengamatan yang dilakukan oleh peneliti masih banyak ibu nifas yang melakukan pantang makanan seperti tidak makan ikan laut, telur dan sayur dengan berbagai alasan diantaranya takut gemuk, luka jahitan lama sembuhnya, darah nifas berbau, gatal-gatal takut bayinya mencret akibat makanan yang mengandung sayur,dan takut bayinya kena sawan. Nutrisi pada ibu post partum sangat penting didalam proses penyembuhan dan untuk kesehatan bayi dalam menerima asupan ASI melalui nutrisi yang dikonsumsi oleh ibu.Bila nutrisi ibu nifas tidak terpenuhi maka proses pemulihan kondisi ibu setelah hamil akan lebih lama dan produksi ASI berkurang, karena didalam tubuh makanan akan diuraikan menjadi suatu zat yang nantinya akan digunakan tubuh untuk menjalankan fungsinya.

Kekurangan gizi pada ibu nifas atau ibu menyusui menimbulkan gangguan kesehatan pada ibu dan bayinya.Gangguan pada bayi mudah sakit, mudah terkena infeksi, kekurangan zat-zat esensial menimbulkan gangguan mata, tulang dan pertumbuhan dan pada ibu nifas akan memperlambat proses penyembuhan luka perineum. Bila ibu tidak memperoleh makanan dengan gizi yang seimbang dapat mengakibatkan ibu kekurangan gizi dan kekurangan darah dan ibu akan memberikan ASI dengan jumlah yang sedikit kurangnya pemenuhan gizi ibu nifas atau menyusui di sebabkan banyak faktor diantaranya adanya pantangan makan pada ibu nifas (Sukma Febi dkk, 2017).

Untuk itu peneliti melakukan penelitian Pengetahuan, Pendapatan dan Makanan Pantangan ibu dengan Pola makan pada Ibu Nifas di Klinik Bersalin Citra, Kabupaten Deli Serdang Tahun 2021.

\section{METODE PENELITIAN}

Jenis penelitian ini adalah merupakan penelitian observasional kuantitatif yang bertujuan untuk mengetahui hubungan hubungan pengetahuan, pendapatan, Makanan Pantangan dengan pola makan ibu nifas di Klinik bersalin Citra. Populasi dari penelitian ini adalah seluruh ibu nifas yang berkunjung di klinik bersalin Citra sebanyak 32 orang. Tekhnik sampel yang digunakan adalah total sampling. Analisis yang dilakukan pada penelitian ini adalah analisis univariat, bivariat dengan tingkat kepercayaan 95 persen $(p=0,05)$ 


\section{HASIL PENELITIAN}

\section{A. Analisis Univariat}

1)

Pengetahuan ibu.

Tabel 4.1 Distribusi Responden Berdasarkan Pengetahuan Ibu dalam Pola Makan

\begin{tabular}{lll}
\hline Pengetahuan & $\mathrm{n}$ & $\%$ \\
\hline Baik & 11 & 33,6 \\
Cukup & 10 & 32,8 \\
Kurang & 11 & 33,6 \\
\hline Jumlah & 32 & 100,0 \\
\hline
\end{tabular}

Dari tabel diatas dapat dilihat bahwa responden yang berpengetahuan baik

2) dan kurang adalah sama sebanyak 11 orang $(33,6 \%)$.

Pendapatan.

Tabel 4.2 Distribusi Frekuensi Responden Berdasarkan Pendapatan Keluarga

\begin{tabular}{lcl}
\hline \multicolumn{2}{c}{ Pendapatan Keluarga Jumlah } & $\%$ \\
\hline Tinggi & 5 & 16,6 \\
Sedang & 15 & 49,1 \\
Rendah & 11 & 34,3 \\
\hline Total & 32 & 100,0 \\
\hline
\end{tabular}

Dari tabel diatas dapat dilihat bahwa responden mayoritas memiliki pendapatan keluarga sedang sebanyak 15 keluarga $(49,1 \%)$.

\section{3) Pola makan}

Tabel 4.3 Distribusi Responden Berdasarkan Pola Makan

\begin{tabular}{llll}
\hline & Pola & & \\
& Makan & Jumlah & $\%$ \\
\hline Baik & 7 & 21,5 \\
Tidak Baik & 25 & 78,5 \\
\hline Total & 32 & 100,0 \\
\hline
\end{tabular}

Dari tabel diatas dapat dilihat bahwa responden memiliki pola makan yang tidak baik sebanyak 25 orang $(78,5 \%)$.

\section{B. Analisis bivariat}

Analisis bivariat digunakan untuk melihat ada tidaknya hubungan antar dua variabel yang ada pada penelitian.

1) Hubungan Pengetahuan dengan pola makan pada ibu nifas di klinik bersalin Citra

Hasil uji chi square untuk hubungan pengetahuan dengan pola makan diperoleh nilai $p$ sebesar $p=0,019$ diartikan bahwaada hubungan antara pengetahuan dengan pola makan ibu nifas di Klinik Bersalin Citra

Tabel 4.4 Hasil Analisis Bivariat antara Pengetahuan dengan Pola Makan 


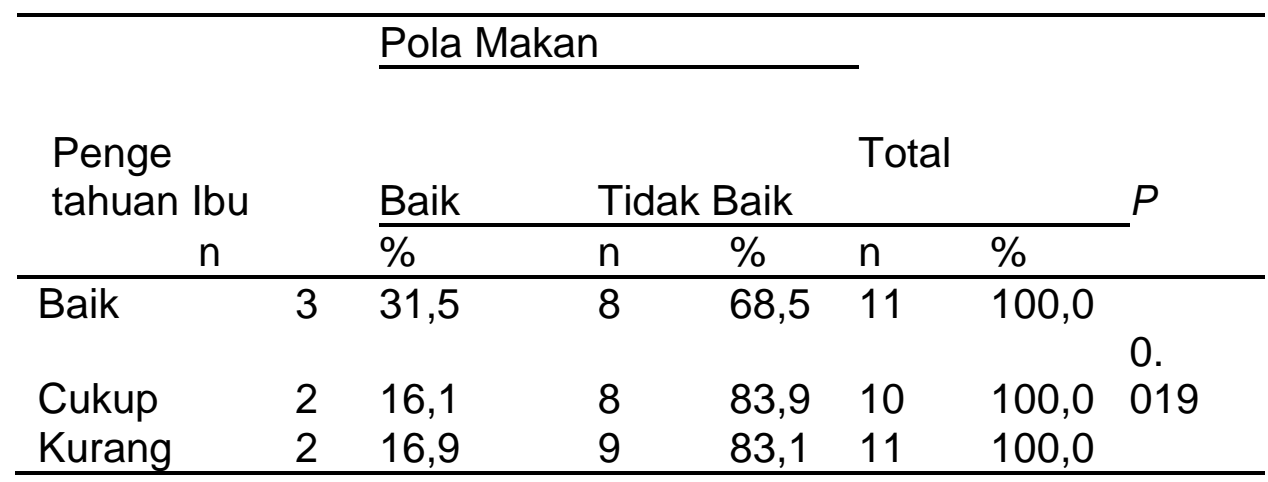

Hasil uji chi square untuk hubungan pengetahuan dengan pola makan diperoleh nilai $p$ sebesar $p=0,019$ diartikan bahwaada hubungan antara pengetahuan dengan pola makan ibu nifas diklinik bersalin Citra.

2) Hubungan pendapatan dengan pola makan pada ibu nifas di klinik bersalin Citra

Tabel 4.5 Hasil Analisis Bivariat antara Pendapatan dengan Pola Makan

\begin{tabular}{|c|c|c|c|c|c|c|c|}
\hline \multicolumn{5}{|c|}{ Pola Makan } & \multirow{2}{*}{\multicolumn{2}{|c|}{ Total }} & \multirow{3}{*}{$P$} \\
\hline \multicolumn{3}{|c|}{ Pendapatan Baik } & \multicolumn{2}{|c|}{ Tidak Baik } & & & \\
\hline & $\bar{n}$ & $\%$ & $\mathrm{n}$ & $\%$ & $\mathrm{n}$ & $\%$ & \\
\hline Tinggi & 6 & 19,8 & 4 & 80,2 & 5 & 100,0 & 0 \\
\hline Sedang & $\begin{array}{l}5 \\
11\end{array}$ & $\begin{array}{l}16,3 \\
344\end{array}$ & 27 & 83,7 & 15 & 100,0 & 017 \\
\hline
\end{tabular}

Hasil uji chi square untuk hubungan pendapatan dengan pola makan diperoleh nilai $p$ sebesar $p=0,017$ diartikan bahwa ada hubungan antara pendapatan dengan pola makan ibu nifas di klinik bersalin Citra.

3) Hubungan makanan pantangan dengan pola makan pada ibu nifas di klinik bersalin Citra

Tabel 4. 6 Hasil Analisis Bivariat antara Makanan Pantangan dengan Pola Makan

\begin{tabular}{llllllll}
\hline \multirow{2}{*}{ Makanan } & \multicolumn{5}{c}{ Pola Makan } & \\
\cline { 2 - 6 } Pantangan & \multicolumn{6}{c}{ Baik } & \multicolumn{5}{c}{ Tidak baik } & \\
\cline { 2 - 7 } & $\mathrm{n}$ & $\%$ & $\mathrm{n}$ & $\%$ & $\mathrm{n}$ & $\%$ \\
\hline Ada & 1 & 17,3 & 6 & 82,7 & 7 & 100,0 & \\
& & & & & & & 0,381 \\
Tidak Ada & 6 & 23,0 & 19 & 77,0 & 25 & 100,0 & \\
\hline
\end{tabular}

Hasil uji analisis bivariat menggunakan uji chi square menunjukkan tidak terdapat hubungan yang signifikan antara dukungan keluarga dengan pola makan $(p=0,3811 ; p>0,05)$. 


\section{PEMBAHASAN}

\section{1) Hubungan Pengetahuan dengan Pola Makan Ibu Nifas di klinik bersalin Citra}

Pola makan adalah rutinitas seseorang dalam mengonsumsi makanan yang dinilai berdasarkan asupan, jenis dan frekuensi makanan yang dikonsumsi sehari-hari.Pola makan diartikan sebagai perilaku dalam mengonsumsi makan pada individu yang dilakukan berulang-ulang untuk memenuhi kebutuhannya sehingga membentuk karekteristik pada setiap orang. Hasil uji analisis bivariat menggunakan uji chi square menunjukkan terdapat hubungan yang signifikan antara pengetahuan ibu dengan pola makan $(p=0,019 ; p<0,05)$

Hasil penelitian ini memberi temuan bahwa pengetahuan berpengaruh secara langsung terhadap pola makan, pengetahuan gizi yang dipunyai oleh seorang ibu akan memberikan informasi-informasi yang tepat pada ibu dalam memilih bahan yang tepat, mengolah makanan yang sehat dan bergizi serta menyajikan makanan yang sehat.

Penelitian ini sejalan dengan penelitian yang dilakukan oleh (Asmawati, 2014)hasil chi square menunjukkan ada perbeda pola makan yang signifikan antara ibu berpengetahuan rendah dan ibu berpendidikan tinggi $(p=0,000)$. Hasil uji lanjut dengan uji kontingensi diperoleh hubungan yang kuat antara pengetahuan gizi ibu dan pola makan $(p=, 000 ; C=0,464)$ semakan baik pengetahuan ibu makan semakin baik pula pola makannya.

Pengetahuan gizi ibu memegang peranan yang sangat penting dalam menggunakan makanan yang baiksehingga dapat mencapai keadaan gizi yang cukup.Tingkat pengetahuan gizi ibu sebagai pengelola rumah tangga akanberpengaruh pada jenis bahan makanan yang dikonsumsi dalam rumah t angga setiap hari(Suhardjo, 2009)

Berdasarkan penelitian (Abdul, 2010) diperoleh hasil uji statistic nilai $p>0,05(p=0,038)$, maka Ha diterima da Ho ditolak berarti ada hubungan antara pengetahuan ibu dengan pola makan gizi seimbang dengan penyembuhan luka perineum di wilayah kerja sipayung.

Dari Uraian diatas penulis berasumsi bahwa pengetahuan memiliki hubungan yang signifikan dengan pola makan di klinik bersalin Citra tahun 2021.

\section{2) Hubungan Pendapatan dengan Pola Makan Ibu Nifas di klinik bersalin Citra}

Sosial ekonomi rumah tangga dapat mempengaruhi kesehatan dan gizi ibuPendapatan keluarga merupakan faktor yang paling menentukan kuantitas dan kualitas makanan dan gizi ibu.Pendapatan keluarga dihitung dari seluruh jumlahanggota keluarga, baik itu dari pekerjaan utama maupun pekerjaansampingan. Tingkat pendapatan juga berpengaruh pada status gizi ibu. 
Kondisi keuangan keluarga memiliki peran yang cukup besar dalam mempengaruhi ketersediaan pangan keluarga.Tingginya presentase keluarga yang tidak memiliki ketersediaan pangan yang terjamin juga didasari mayoritas pekerjaan responden yang bekerja sebagai petani, pedagang, buruh, kuli bangunan dan pekerja serabutan yang memiliki pendapatan rendah sehingga sulit memenuhi kebutuhan rumah tangga salah satunya menjamin pola makan yang baik.

Tersedianya pangan yang cukup jumlahnya dan berkualitas membuat asupan zat gizi keluarga terpenuhi.Asupan gizi yang baik akan berdampak pada kesehatan keluarga secara keseluruhan termasuk status gizi anak. Keluarga yang tidak mampu menyediakan pangan yang cukup dan bergizi terlebih dalam waktu panjang akan mengakibatkan timbulnya masalah gizi.

Pada penelitian ini analisis bivariat menunjukkan ada hubungan yang signifikan antara pendapatan dengan pola makan ibu nifas di Kabupaten Tapanuli Selatan dengan nilai sebesar $p=0,017$. Hasil penelitian ini sejalan dengan penelitian yang dilakukan oleh (Widyantara, Wiyana, \& Sarini, 2013) adanya hubungan yang kuat antara tingkat pendapatan dengan pola makan, pada daerah ini harga bahan makanan cukup tinggi sehingga rumah tangga dengan pendapatan rendah tidak mampu untuk membeli bahan makanan yang beranekaragam dan pada umumnya masyarakat menanami lahan sekitar rumah mereka dengan bahan makanan pokok seperti ubi jalar, singkong, jagung dan talas, selain untuk dikonsumsi sendiri juga untuk dijual kepasar dan pada kenyataannya makanan pokok yang dijual lebih baik kualitas maupun kuantitas dibanding yang dikonsumsi sendiri.

Pola makan yang baik tidak dapat terwujud ketika keluarga tersebut tidak memiliki pendapatan yang mampu memenuhi makanan berkualitas baik

disebabkan karena besarnya pendapatan keluarga akan memengaruhi daya beli keluarga, khususnya dalam pemenuhan kebutuhan makanan. Keluarga yang memiliki tingkat pendapatan yang tinggi akan menggunakan pendapatan tersebut untuk mencukupi kebutuhan makan keluarga, sehingga gizi keluarga terpenuhi pegitu pula sebaliknya jika keluarga memiliki tingkat pendapatan yang rendah maka akan kesulitan dalam memenuhi kebutuhan gizi untuk anggota keluarganya.

Dalam penelitian ini karena terbatasnya pendapatan yang diperoleh keluargamenyebabkan makan dan minum tidak sepenuhnya di prioritaskan karena masih banyak kebutuhan lain yang harus dipenuhi, misalnya kebutuhan sekolah, rumah tangga seperti listrik, air, dan sebagainya.

\section{3) Hubungan Makanan Pantangan dengan Pola Makan Ibu Nifas di Klinik bersalin Citra}

Hasil uji analisis bivariat menggunakan uji chi square menunjukkan tidak terdapat hubungan yang signifikan antara makanan pantangan dengan pola makan $(p=0,381 ; p>0,05)$. Nilai rasio prevalens yakni 701 mengartikan bahwasanya rasio prevalens pola makan tidak baik pada responden yang memiliki makanan pantangan 701 kali lebih besar terjadi dibandingkan pada responden yang tidak memiliki makanan pantangan. 
Berdasarkan penelitian (Pelto, 1981) diperoleh nilai chi square menunjukkan nilai $p=0,341 p>0,05$ maka makanan pantangan secara statistic tidak memiliki hubungan yang signifikan terhadap pola makan responden, berdasarkan hasil wawancara dengan responden satu orang responden mengatakan bahwa tidak mengkonsumsi makanan hasil laut seperti ikan, udang, cumi-cumi maupun kepiting, hal ini bukan saja dilakukan setelah yang bersangkutan hamil melainkan sudah diterapkan dari zaman nenek moyang, bahkan sampai suami dan anaknya juga mengikuti kebisaan tersebut. Hal ini sejalan dengan penelitian di Tapanuli Selatan mayoritas ibu nifas memiliki makanan pantangan yaitu sayur sawi dan makanan pedas, ada beberapa resonden yang tidak memakan ikan dan telur dengan alasan alergi pada kulit.Menurut responden jika mereka tidak dapat mengkonsumsi salah satu jenis makanan tersebut mereka dapat menggantikannya dengan jenis makanan lain yang tidak kalah nilai gizinya.

Menurut (Khomsan, 2000)menyatakan bahwa makanan yang dikonsumsi manusia digunakan untuk mempertahankan kelangsungan hidupnya, tetapi ada yang beranggapan bahwa satu atau beberapa makanan dianggap berbahaya bagi seseorang yang memakannya. Makanan pantangan merupakan perilaku seseorang untuk tidak mengkonsumsi makanan tertentu.Tidak terdapat hubungan yang signifikan antara makanan pantangan terhadap pola makan ibu nifas disebabkan jenis makanan yang dipantangkan memiliki kontribusi energy yang kecil dan tidak memiliki zat gizi yang tinggi yang dapat memengaruhi zat gizi ibu nifas yaitu sawi dan makanan pedas (cabe).

\section{SIMPULAN DAN SARAN}

\section{SIMPULAN}

Dari hasil penelitian yang dilakukan peneliti dapat menyimpulkan bahwa kesimpulan bahwa terdapat hubungan signifikan antara pengetahuan ibu dengan pola makan ibu nifas $(p=0,019)$, pendapatan dengan pola makan ibu nifas $(p=0,017)$, namun untuk makanan pantangan tidak ada hubungan makanan pantangan dengan pola makan ibu nifas $(p=0,38)$.

\section{SARAN}

Disarankan bagi petugas kesehatan dapat memberikan KIE (komunikasi, informasi dan edukasi) kepada masyarakat mengenai pola makan ibu nifas bagaimana pola makan yang baik agar kesehatan ibu tetap terjaga. 


\section{DAFTAR PUSTAKA}

Asih Yusari \& Risneni. (2016). Buku Ajar Asuhan Kebidanan Nifas dan. Menyusui. Trans Info Media.

Azizah, N., \& Rosyidah, R. (2021). Buku Ajar Mata Kuliah Asuhan Kebidanan Nifas dan Menyusui. Umsida Press. https://doi.org/https://doi.org/10.21070/2019/978602-5914-78-2

Istiany, Ari dan Rusilanti. (2013). Gizi Terapan. PT Remaja. Rosdakarya.

Kemenkes. (2019). Profil Kesehatan Indoneisa 2019. In Kementerian Kesehatan Republik Indonesia.

Kemenkes. (2020). Pedoman Bagi Ibu Hamil, Ibu Nifas Dan Bayi Baru Lahir. Pedoman Bagi Ibu Hamil , Ibu Nifas Dan Bayi Baru Lahir Selama Covid-19, 8-9.

Mahayati, L. (2015). Faktor-faktor yang mempengaruhi ibu dalam pemenuhan nutrisi pada masa nifas di bps mien hendro sidoarjo. Jurnal Keperawatan, 4(2), 9Pages.

Pinem,S.P.,dkk. (2020). Buku Ajar Asuhan Kebidanan Masa Nifas dan Menyusui. AA.Rizky.

Prawirohardjo, S. (2011). Ilmu Kebidanan. Bina Pustaka Sarwono Prawirohardjo.

Ramadhani, A. S., Astawan, M., \& ... (2015). Pola Konsumsi Pangan lbu Pasca Melahirkan di RSIA Thaha Bakrie Samarinda (Postpartum Food Consumption Pattern at RSIA Thaha Bakrie Samarinda). Jurnal Mutu Pangan ..., 2(2), 136143. http://journal.ipb.ac.id/index.php/jmpi/article/view/27473

Sugiyono. (2014). Metode Penelitian Pendidikan Pendekatan Kuantitatif,. Kualitatif, dan $R \& D$. Alfabeta.

Sukma Febi dkk. (2017). Asuhan Kebidanan Pada Masa Nifas. Fakultas Kedokteran dan Kesehatan Universitas Muhammadiyah.

Sulistyoningsih,H. (2011). Gizi untuk kesehatan ibu dan anak. Graha Ilmu.

Walyani, ES., \& Purwoastuti, E. (2017). Asuhan Kebidanan Masa Nifas Dan Menyusui. Pustaka Baru Press. 